\title{
First record of Xylocopa valga GERSTAECKER, 1872 from the cold and arid conditions of Ladakh in India (Hymenoptera: Apidae: Xylocopini)
}

\author{
Umer BIN FAROOK ${ }^{1 *}$ (D) - Munazah YAQOOB ${ }^{2}$ (D) $\cdot$ Mudasir GANI $^{3}$ (D) - Fons VeRHEYDE ${ }^{4}$ (D)
}

Bin Farook, U., M. YAQOob, M. Gani \& F. Verheyde (2021). First record of Xylocopa valga GerstaeCKer, 1872 from the cold and arid conditions of Ladakh in India (Hymenoptera: Apidae: Xylocopini). Osmia, 9: 59-64. https://doi.org/10.47446/OSMIA9.8

\begin{abstract}
The presence of Xylocopa valga is reported for the first time from the high altitudes of Union Territory of Ladakh (more than 3,000 $\mathrm{m}$ above sea level), India. Several bees were observed in the area from May 2019 to September 2020, where it is considered to be a pest because of its aptness for making nests in residential and commercial buildings. The species has likely expanded its geographical area due to environmental changes. It is important to disseminate knowledge among Ladakh people about this bee to ensure the preservation of its populations.
\end{abstract}

Keywords $\mid$ Asia $\cdot$ carpenter bee $\cdot$ conservation $•$ environmental management

Premier signalement de Xylocopa valga GeRSTAECKER, 1972 dans les conditions froides et arides du Ladakh en Inde (Hymenoptera : Apidae: Xylocopini)

\begin{abstract}
Résumé
La présence de Xylocopa valga est reportée pour la première fois dans les territoires du Ladakh en Inde (plus de 3000 m d'altitude). Plusieurs individus ont été observés sur ce territoire entre mai 2019 et septembre 2020. L'espèce y est considérée comme nuisible par la population à cause de sa capacité à faire des nids dans les bâtiments commerciaux et résidentiels. Cette espèce a probablement étendu son aire de répartition à cause des changements environnementaux. II apparaît important de communiquer autour de cette espèce auprès de la population de Ladakh pour préserver ses populations.
\end{abstract}

Mots-clés $\mid$ Asie • abeille charpentière $•$ conservation • gestion environnementale

Reçu•Received | 29 May 2021 || Accepté • Accepted | dd November 2021 || Publié (en ligne) • Published (online) | dd November 2021 Reviewers |S. CHABERT • P. LHOMME || http://zoobank.org/261B36CE-1632-4381-933F-DDCCCAA62EE2

\section{INTRODUCTION}

Xylocalpa valga is very widely distributed in the Palearctic and reported here for the first time from the Ladakh-region in India. Its presence is known from Europe (Albania, Austria, Bulgaria, Corsica, Crete, the Czech Republic, Estonia, France, Hungary, Italy, Lithuania, Poland, Portugal, Romania, Sicily, Slovenia, Spain, Switzerland and West-Russia), Asia (China, Georgia, Kazakhstan, Kyrgyzstan, Macedonia, Mongolia, Tajikistan, Turkmenistan, Ukraine and Uzbekistan), the Middle East (Armenia, Iran, Israel, Pakistan and Turkey) and North-Africa (Algeria and Morocco) (MICHENER, 2007; WU,
1982; MA, 1938; HURD, 1955, 1978; EARDLEY, 1983). It was also reported in India from other localities, notably Kashmir (ARA et al., 2019). Ladakh is a newly created union territory of India located in the northernmost side of Jammu and Kashmir, India between $32^{\circ} 15^{\prime}$ to $36^{\circ} \mathrm{N}$ and $75^{\circ} 15^{\prime}$ to $80^{\circ} 15^{\prime} \mathrm{E}$. It covers an area of approximately $98,000 \mathrm{~km}^{2}$ (AKHTAR \& WILLIAM, 2019). Regarding the mellitofauna, many studies in Northwestern Himalayas have been conducted in different agroecological areas where different (solitary) bees were reported.

\footnotetext{
1 [UBF] Division of Entomology, Sher-e-Kashmir University of Agricultural Sciences and Technology of Kashmir, Wadura Sopore, 193201 Kashmir, India umerskuast@gmail.com (*corresponding author) (D) https://orcid.org/0000-0001-6770-1272 • zoo:ank http://zoobank.org/C857B334-DA16-4928-B2EE-6A813B9F1236

2 [MY] Division of Entomology, Sher-e-Kashmir University of Agricultural Sciences and Technology of Kashmir, Wadura Sopore, 193201, Kashmir, India munazah_123@rediffmail.com

(D) https://orcid.org/0000-0001-9308-6349 • zoo:ank http://zoobank.org/EA6AB7AA-5F5D-4ED7-AF50-9EB338AEA7DD
}

3 [MG] Division of Entomology, Sher-e-Kashmir University of Agricultural Sciences and Technology of Kashmir, Wadura Sopore, 193201, Kashmir, India mudasir32@gmail.com

(i) https://orcid.org/0000-0003-4410-9924 • zoo:ank http://zoobank.org/113E4996-6EBC-4FD4-B22A-C072C2873030

4 [FV] Independent researcher, Aartshertoginnestraat 58/01, B - 8400 Ostend, Belgium • fonsverheyde@hotmail.com (D) https://orcid.org/0000-0002-2240-9689 • ZooBank http://zoobank.org/D197B5B4-00FF-4D57-924D-EFF926A99119 
Worldwide, there are approximately 995 species and 15 genera within the subfamily Xylocopinae, of which 59 species have been reported from India. 19 Of those are situated in the genus Xylocopa (ASCHER et al., 2008). The species of Xylocopa (Hymenoptera: Apoidea: Apidae: Xylocopinae) recorded so far in temperate conditions are Xylocopa valga GERSTÄCKER, 1872 and Xylocopa violacea (LINNAEUS, 1758) (RAJU \& PURNACHANDRA MATTU, 2014; ARA et al., 2019), while, in sub-tropical conditions, Xylocopa collaris LEPELETIER, 1841, Xylocopa fenestrate (FABRICIUS, 1758), Xylocopa latipes (DRURY, 1773) and Xylocopa pubescence SPINOLA, 1838 (ABROL et al., 2012; TARA et al., 2014) were reported.
However, no systematic work has been done in the cold and semi-arid conditions of Union Territory of Ladakh (UT Ladakh hereafter) in India, for Xylocopa.

In order to formulate conservation policies for any species, one needs information regarding its ecology and habitat. This study was intended to generate baseline data regarding species of Xylocopa by documenting diversity across different landscapes which in turn may help understanding their pollination services in various agro-ecosystems across the area.

\section{MATERIALS AND METHODS}

\section{Study area and sampling design}

The samplings were conducted in various localities/villages/cities of Kargil to assess the presence of Xylocopa species on different agricultural, horticultural and ornamental plants from April 2019 to September 2020. Locations were chosen on the basis of the abovementioned vegetation which could be typified as dominant (and typical) for certain ecotypes in the region of Ladakh, e.g. pulses, buckwheat, ornamental flours, fruit trees, etc. (see also table I). For practical reasons (the distance which had to be travelled), locations were only visited once each year.

\section{Insect collection and killing}

Specimens were collected with a sweep net of nylon cloth and killed with ethyl acetate in a jar.

\section{Processing of specimens}

The collected specimens were sorted, spread and pinned using insect pins (size No. 1, 2 and 3). Tongue, mandibles, antennae, legs and wings were stretched properly. The processed specimens were permanently labelled giving details of locality, date of collection, host plants and collector name. Specimens examined were deposited in the Division of Entomology, FoA, Wadura, SKUAST-K, India.

\section{Diagnostics of Xylocopa valga}

The tribe Xylocopini comprises only one single genus, Xylocopa, which consists of large and robust bees (13 to $30 \mathrm{~mm}$ long). Their general appearance greatly differs from other tribes of the subfamily Xylocopinae. Principal characters of the genus are the loss of the stigma, the very long prestigma and marginal cell (DANFORTH, 1989). The head is transverse, and the ocelli form a triangle just below the vertex. The antennae are geniculate, the scape sometimes dilated or incrassate. The distal parts of the wings are strongly papillate, while the forewing has an elongated radial cell, acute at apex, and three cubital cells: the third longest, the second subtriangular (MICHENER, 2007).

Next to the specific size (more than $22 \mathrm{~mm}$ ), colouration, punctuation (sparse on the head), pubescence (brownishblack hair) are important structural characters to separate $X$. valga from other species in the (sub)genus which have entirely black antenna and the hind tibia with 5 to 6 longitudinal series of denticles (AMIET et al., 2007; MICHENER, 2007).

Males and females of X. valga are similar in morphology (figure 1). Females are black (figure 1a), larger than males (figure 1b) $(28-30 \mathrm{~mm}$ vs. $22-28 \mathrm{~mm}$ ) and their wings display a purple iridescence. The mandible contains two teeth. On the outer apex of the hind tibia two spines account for two-third of the tibial length and scopa are found on the hind leg (basitarsus) to collect pollen. The male is also black, with larger eyes, which is also typical for other Xylocopa species. The head is smaller (figure 1d) than that of the females (figure 1c) and the wings are brownish-purple. There is no scopa on the hind leg of the males (figure 1b). Apart from a small amount of black hair on the anterior surface of the head, the body is covered with brownish-black hair.

\section{RESULTS}

The study revealed the occurrence of Xylocopa valga for the first time in UT Ladakh. Overall, 42 specimens of $X$. valga were collected in eight locations located between 2,630 and
3,345 $\mathrm{m}$ above sea level, foraging on 25 wild and grown plant taxa belonging to several plant families. $78.6 \%$ of the collected specimens were females (see Table I). 


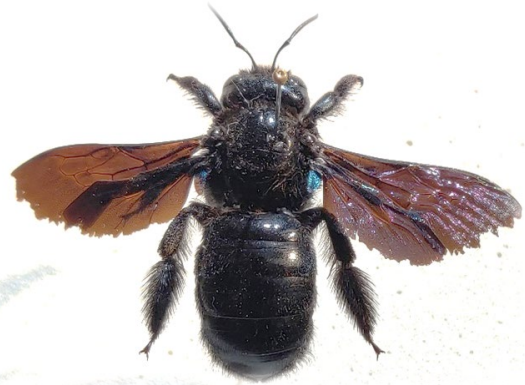

a

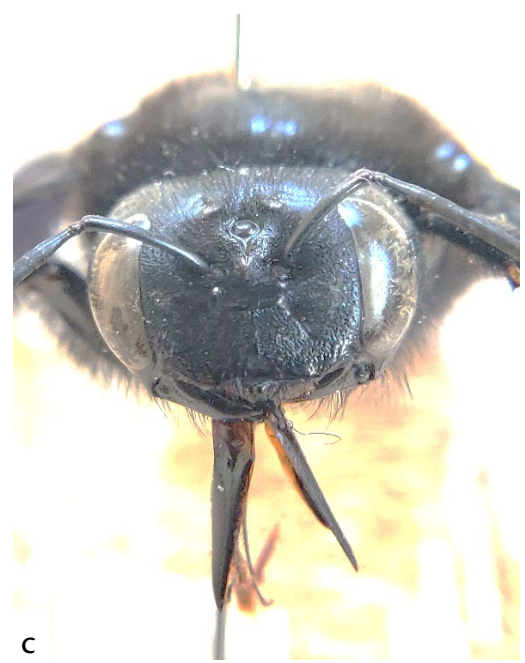

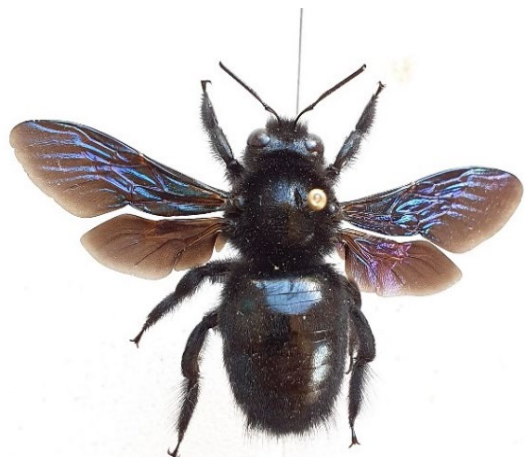

b

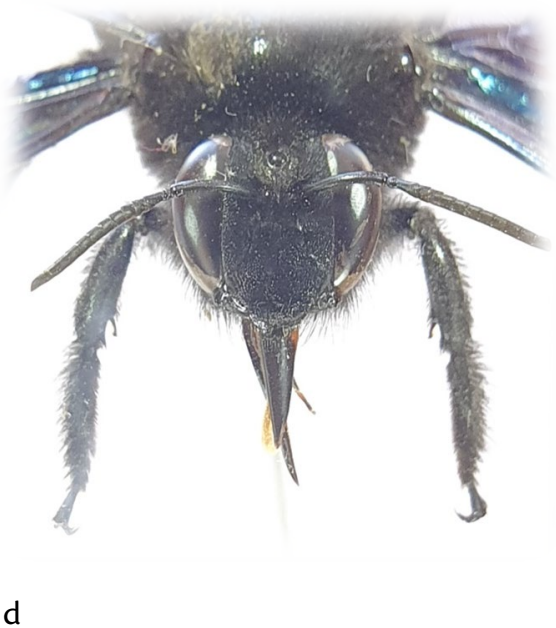

Figure 1. Xylocopa valga a. Female of X. valga. b. Male of X. valga. c. Head of female. d. Head of male.

Table I. Materials examined from Kargil (UT of Ladakh, India).

\begin{tabular}{|c|c|c|c|c|c|c|c|}
\hline \multirow[b]{2}{*}{ Site of sampling } & \multirow[b]{2}{*}{$\begin{array}{l}\text { Date of } \\
\text { collection }\end{array}$} & \multicolumn{2}{|c|}{ Specimens } & \multirow[b]{2}{*}{$\begin{array}{l}\text { Altitude } \\
(\mathrm{m})\end{array}$} & \multirow[b]{2}{*}{$\begin{array}{l}\text { Geographical } \\
\text { coordinates }\end{array}$} & \multirow[b]{2}{*}{$\begin{array}{l}\text { Name of the } \\
\text { collector }\end{array}$} & \multirow[b]{2}{*}{ Host plants } \\
\hline & & $\begin{array}{l}\text { Females } \\
(q \circ)\end{array}$ & $\begin{array}{l}\text { Males } \\
\left(\hat{\partial} \partial^{\lambda}\right)\end{array}$ & & & & \\
\hline Baroo & $\begin{array}{l}\text { 14-VII-2019, } \\
08-\mathrm{VI}-2020\end{array}$ & 3 & 1 & 2654 & $\begin{array}{l}34^{\circ} 32^{\prime} 42^{\prime \prime N} \\
76^{\circ} 08^{\prime} 34^{\prime \prime} \mathrm{E}\end{array}$ & Umer BIN FAROOK & Trifolium pratense L., Trifolium repens L. \\
\hline Drass & $\begin{array}{l}\text { 11-V-2019, } \\
13-\mathrm{VIII}-2020\end{array}$ & 5 & 0 & 3265 & $\begin{array}{l}34^{\circ} 25^{\prime} 59^{\prime \prime} \mathrm{N} \\
75^{\circ} 45^{\prime} 37^{\prime \prime} \mathrm{E}\end{array}$ & Umer BIN FAROOK & $\begin{array}{l}\text { Phaseoulus vulgaris } \mathrm{L} ., \text { Cucumis melo L., } \\
\text { Trifolium repens L., Trifolium pratense } \mathrm{L} \text {. }\end{array}$ \\
\hline KVK Kargil & $\begin{array}{l}28-V \mid I I-2019 \\
5-I X-2020\end{array}$ & 6 & 2 & 2670 & $\begin{array}{l}34^{\circ} 31^{\prime} 13^{\prime \prime N} \\
76^{\circ} 08^{\prime} 35^{\prime \prime} \mathrm{E}\end{array}$ & Umer BIN FAROOK & $\begin{array}{l}\text { Solanum tuberosum L., Tegetes spp. L., Malus } \\
\text { domestica Borkh, Pyrus spp. L., Zinnia spp. }\end{array}$ \\
\hline Minjee & $\begin{array}{l}\text { 24-VI-2019, } \\
17-\mathrm{VIII}-2020\end{array}$ & 4 & 1 & 2676 & $\begin{array}{l}34^{\circ} 29^{\prime} 10^{\prime \prime} \mathrm{N} \\
76^{\circ} 06^{\prime} 06^{\prime \prime} \mathrm{E}\end{array}$ & $\begin{array}{l}\text { Abdul MAJEED \& } \\
\text { Umer BIN FAROOK }\end{array}$ & $\begin{array}{l}\text { Phaseoulus vulgaris } \mathrm{L} ., \text { Cucumis melo } \mathrm{L} ., \\
\text { Trifolium repens L., Trifolium pratense } \mathrm{L} \text {. }\end{array}$ \\
\hline Sankoo & $\begin{array}{l}\text { 08-VII-2019, } \\
21-\mathrm{VIII}-2020\end{array}$ & 2 & 1 & 2630 & $\begin{array}{l}34^{\circ} 17^{\prime} 31^{\prime \prime N} \\
75^{\circ} 57^{\prime} 39^{\prime \prime} \mathrm{E}\end{array}$ & Umer BIN FAROOK & $\begin{array}{l}\text { Zinnia spp., Dahlia spp., Taraxacum officinale } \\
\text { Weber, Trifolium repens L., Trifolium pratense } \\
\text { L. }\end{array}$ \\
\hline Trespoon & $\begin{array}{l}\text { 6-VII-2019, } \\
11-\mathrm{VIII}-2020\end{array}$ & 7 & 2 & 2650 & $\begin{array}{l}34^{\circ} 25^{\prime} 20^{\prime \prime} \mathrm{N} \\
76^{\circ} 03^{\prime} 00^{\prime \prime} \mathrm{E}\end{array}$ & Umer BIN FAROOK & $\begin{array}{l}\text { Solanum tuberosum L., } \\
\text { Phaseoulus vulgaris L., Cucumis melo L., Zinnia } \\
\text { spp., Dahlia spp., Taraxacum officinale Weber, } \\
\text { Trifolium repens L., Trifolium pratense L. }\end{array}$ \\
\hline Batalik & $\begin{array}{l}\text { 27-VI-2019, } \\
01-\mathrm{VIII}-2020\end{array}$ & 0 & 0 & 3345 & $\begin{array}{l}34^{\circ} 39^{\prime} 23^{\prime \prime} \mathrm{N} \\
76^{\circ} 20^{\prime} 23^{\prime \prime} \mathrm{E}\end{array}$ & - & - \\
\hline $\begin{array}{l}\text { Research } \\
\text { station Kargil }\end{array}$ & $\begin{array}{l}10-\mathrm{VIII}-2019 \\
03-\mathrm{IX}-2020\end{array}$ & 10 & 3 & 2700 & $\begin{array}{l}34^{\circ} 32^{\prime} 19^{\prime \prime} \mathrm{N} \\
76^{\circ} 09^{\prime} 04^{\prime \prime} \mathrm{E}\end{array}$ & Umer BIN FAROOK & $\begin{array}{l}\text { Tegetes spp. L., Malus domestica Borkh, Pyrus } \\
\text { spp. L., \& Zinnia spp., Trifolium repens L., } \\
\text { Trifolium pratense L. }\end{array}$ \\
\hline
\end{tabular}

\section{DISCUSSION}

The discovery of X. valga in the high altitudes of Ladakh shows that the range of this species has been expanding, possibly owing to the changing thermal conditions within the region. Although references are scarce in literature from neighbouring countries, there are at least some indications the species has been expanding only recently, notably in China where it has been reported from Inner Mongolia to
Tibet and northwestern regions with higher altitudes ( $\mathrm{HE}$ \& ZHU, 2020). It is very likely that the environment and habitat is getting more suitable for $X$. valga. On the one hand, there is an abundance of several agri- and horticultural vegetation as well as ornamental plants cultivated in neighbouring villages and town settlements that are used for feeding and to collect pollen. On the other hand, there is a surplus of 
wood material that can be used for nesting (HE \& ZHU, 2020). In our case, females were observed nesting in poplar (Populus spp.) and occasionally in willow wood (Salix spp.). Both feeding and nesting facilities are key factors in stabilizing the population of $X$. valga. The response of the local people towards $X$. valga has been rather negative in spite of its ecological importance (RAJU \& PURNACHANDRA RAO, 2006;
KEASAR, 2010). This is primarily because of its potential to damage local, commercial and cultural property besides being physically intimidating. Therefore, a proper knowledge of the carpenter bees' use and beauty will have to result in a broader awareness to base consequent actions upon (i.e. damage control for certain buildings; see GAO et al., 2020 for an example).

\section{ACKNOWLEDGEMENTS}

We are highly thankful to the Project Coordinator, Dr. Ahmed FaIZAN from Mountain Agricultural Research Institute Kargil, for his timely support and help, as well as other researchers and farmers of village Minji who shared their valuable experiences and information regarding $X$. valga in this region for the untroubled survey. We thank Dr. Stan ChABerT (University of Florida) and Dr. Patrick LHOMME (University of Mons) for reading the manuscript and reviewing our paper.

\section{Conflict of interests}

The authors declare that they have no conflict of interest.

\section{Data availability statement}

The data that support the findings of this study are available from the corresponding author upon reasonable request. 


\section{REFERENCES}

Abrol, D. P., U. Shankar, D. Chatterjee \& V. V. Ramamurthy (2012). Exploratory studies on diversity of bees with special emphasis on non-Apis pollinators in some natural and agricultural plants of Jammu division, India. Current Science, 103(7): 780-783. https://www.jstor.org/stable/24088834

AKHTAR, R. \& K. WiLLIAM (2019). "Jammu and Kashmir, Union Territory, India". Encyclopedia Britannica. [accessed 7 August 2019]

Amiet F., M. Hermann, A. Müller \& R. Neumeyer (2007). Fauna Helvetica 20. Apidae 5. Centre suisse de cartographie de la faune, Neuchâtel (Switerzland), $241 \mathrm{pp}$.

Ara, S., Z.A. Rather, M. A. Paray, R. Khursheed \& M. Yaqoob (2019). Bee flora of Kashmir: The Himalayan biodiversity hotspot. Journal of Pharmacognosy and Photochemistry, 8(2): 21722182.

https://www.phytojournal.com/archives?year $=2019 \& \mathrm{vol}=8 \&$ is sue $=2 \&$ Articleld $=7998$ [accessed 11 October 2021]

Ascher, J., C. Eardley, T. Griswold, G. Melo, A. Polaszek, M. RugGiero, P. Williams, K. Walker \& N. Warrit (2008). World Bee Checklist Project update 200809, manuscript (version 10/09/2008). Integrated Taxonomic Information System.

https://www.itis.gov/servlet/SingleRpt/RefRpt?search_type=s ource\&search_id=source_id\&search_id_value $=446$ [accessed 10 October 2021]

DANFORTH, B. N. (1989). The evolution of hymenopteran wings: The importance of size. Journal of Zoology, 218(2): 247-276. https://doi.org/10.1111/j.1469-7998.1989.tb02536.x

GAO, Y., D. XU, E. LI, J. LI, Z. Ge \& Y. Zhou (2020). Preventive monitoring and study of insect damage of carpenter bees to timber components of Chinese historic buildings, pp. 87-92. In: A. Vandesande, E. Verstrynge \& K van Balen (ed.). Preventive Conservation, Taylor \& Francis, London, $162 \mathrm{pp}$. https://doi.org/10.1201/9781003004042-13

$\mathrm{HE}, \mathrm{C}$ \& \& C. ZHU (2020). Nesting and foraging behavior of Xylocopa valga in the Ejina Oasis, China. PLoS ONE, 15(7):e0235769.

https://doi.org/10.1371/journal.pone.0235769
HURD, P. D. Jr. (1955). The carpenter bees of California. Bulletin fo the California Insect Survey, 4(2): 35-72.

https://essig.berkeley.edu/documents/cis/cis04_2.pdf [accessed 10 October 2021]

HURD, P. D. Jr. (1978). An Annotated Catalog of the Carpenter Bees (Genus Xylocopa LATREILLE) of the Western Hemisphere (Hymenoptera: Anthophoridae). Smithsonian Institution Press, Washington D.C., 106 pp.

KalA, C. P. (2011). Floral Diversity and Distribution in the High Altitude Cold Desert of Ladakh, India. Journal of Sustainable Forestry, 30(5): 360-369. https://doi.org/10.1080/10549811.2011.534036

KEASAR, T. (2010). Large carpenter bees as agricultural pollinators. Psyche, 8:1-7. https://doi.org/10.1155/2010/927463

MICHENER, C. D. (2007). The bees of the world. $2^{\text {nd }}$ edition. The Johns Hopkins University press, $913 \mathrm{pp}$.

Raju, A. J. S. \& S. PuRnachandRa RaO (2006). Nesting habits, floral resources and foraging ecology of large carpenter bees (Xylocopa latipes and Xylocopa pubescens) in India. Current science, 90:1210-1217. https://www.jstor.org/stable/24092022

TARA, J.S., N. Zaffar, M. Gupta \& A. Bala (2014). Hymenopteran insect pollinators on apple bloom in district Rajouri, Jammu (J\&K), India. International Journal of Interdisciplinary and multidisciplinary studies, 1(8):168-171.

http://www.ijims.com/uploads/eff1e49b0c9eff46ecc3A23.pdf [accessed 11 October 2021]

THAKUR, B. \& V.K. MATTU (2014). Diversity and distribution of insect pollinators on various temperate fruit crops in Himachal Himalayas, India. International Journal of Science and Nature, 5(4): 626-631.

https://www.ajabs.org/articles/diversity-and-distribution-ofpollinators-of-temperate-fruit-crops-ofshimla-hills-inhimachal-pradesh.pdf [accessed 11 October 2021]

WU, Y. (1982). A study on Chinese Xylocopa with description of a new species. Zoological Research, 3(2): 193-200. http://www.zoores.ac.cn/en/article/id/1586 [accessed 10 October 2021]

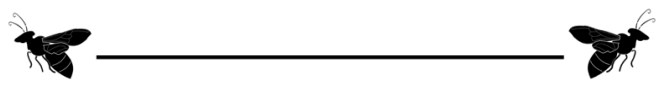


OSMIA est éditée par I'Observatoire des Abeilles (OA), une association loi 1901 d'apidologues (ou mellitologues) d'Europe francophone qui œeuvrent pour la connaissance et la protection des Abeilles sauvages

Les articles sont:

- publiés uniquement en ligne

- disponibles en open access,

- indexés / archivés par Crossref Zoobank HAL, Zenodo OpenAIRE, Google Scholar et Web of Science (Clarivate) OpenAIRE, Google
[Zoological Record]

- respectueux des recommandations de la Commission internationale de Nomenclature zoologique (ICZN),

sous Licence Creative Commons Attribution International CC BY 4.0 qui autorise la reproduction et la diffusion du document, à condition d'en citer explicitement la source,

- librement déposables sur des sites internet ou des plateformes d'archivage.

(!) Les documents d'autres sources et non distribuées sou licence libre sont reproduits après autorisation (à demander par les auteurs) et demeurent la propriété des auteurs ou éditeurs originaux.

(!) Le contenu publié est sous l'entière responsabilité des (!) Le conte
auteurs.

OSMIA est conçue pour une impression recto-verso en haute résolution. Les bibliothèques publiques, les laboratoires, les muséums et les associations sont invités à imprimer et conserver une version papier de la revue.
OSMIA is published by the Observatory of Bees (OA), a nonprofit society of apidologists (or mellitologists) from Frenchspeaking Europe who work together for the knowledge and protection of wild bees.

The items are:

- published only online

- available in open access

- indexed / archived by Crossref, Zoobank, HAL, Zenodo, OpenAIRE, Google Scholar and Web of Science (Clarivate) OpenAIRE, Google Sc

- respectful of the recommendations of the International Commission for Zoological Nomenclature (ICZN)

under Creative Commons Attribution Licence International CC BY 4.0 which authorises the reproduction and distribution of the document, provided the source is explicitly cited

freely depositable on personal or institutional websites and archiving platforms.

(!) Documents from other sources and not distributed under a free license are reproduced after authorisation (to be requested by the authors) and remain the property of the original authors or publishers.

(!) The published content is the sole responsibility of the (!) The

OSMIA is designed for high-resolution printing on both sides. Public libraries, laboratories, museums, and societies are invited to print and keep a paper version of the journal.
Directeur de la publication - Editor-in-chief Benoit GESLIN

Comité éditorial • Editorial Board

Matthieu AUBERT • Floriane FLACHER • Mehdi ISSERTES

Tanguy JEAN • Léa LEMAIRE

Mise en page $\cdot$ Layout

Mehdi ISSERTES • Tanguy JEAN • Léa LEMAIRE

Comité de lecture • Scientific committee 2021 https://www.osmia-journal-hymenoptera.com/equipe-team.html

Soumission d'articles • Submission of items osmia.editor@gmail.com

Recommandations aux auteurs . Recommendations to authors https://www.osmia-journal-hymenoptera.com/auteurs-authorsinstructions.html

Observatoire des Abeilles

68 rue du Onze Novembre

F - 59148 Flines-lez-Râches (France)

https://oabeilles.net/

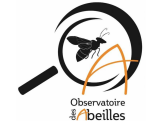

OPEN

Access 